3014

日本機棫学会論文集 (C 編)

51 巻 471 号 (昭 60-11)

論文 No. 84-0595 A

\title{
任意形状コイルばねの振動*
}

長屋幸助**, 武田定彦**, 中田貴隆***

\section{Vibration of Coil Springs with Arbitrary Shape}

by Kosuke NAGAYA, Sadahiko TAKEDA, and Yoshitaka NAKATA

\begin{abstract}
This paper is concerned with the method for analyzing the vibration of coil springs with arbitrary shape. In the analysis, the field transfer matrix is derived from the solution of the foundamental equation of the curved beam theory. The transfer matrix is given by combining this field transfer matrix and the point transfer matrix. The analysis derives the frequency equation which is applicable to the coil spring of general shape. Numerical calculations have been carried out for HYPERBOLOIDAL springs and barrel springs. Experimental tests are also carried out to verify the present theoretical results.
\end{abstract}

Key Words: Machine Elements, Vibration, Coil Spring, Surging, Transfer Matrix, HYPERBOLOIDAL Spring, Barrel Spring

\section{1. 緒言}

ばねは機械の基礎的な要素で古くから注目され，そ の応力問題(1) (11), および振動問題(12) (14)については多 くの研究がなされてきた.とくに、ばねのサージング は機械に重大な悪影響を及ぼすため，井上，清水 $ら^{(12)(13)}$ および沢登ら ${ }^{(14)} に よ り$, 詳細な検討がなされ ている.しかし、これらはいずれも円筒コイルばねの 問題を取扱っており, それ以外の形状のばねの振動を 取扱ったものはほとんど見受けられないようである. しかし実際には異形ばねも多くの分野で使用されてお り，今後ますますその使用範囲が広がりつつあり，そ の振動特性を解明することは重要なことと思われる。 本報はこれらの現状にかんがみ，任意形状ばねの振動 問題の理論解析を行うとともに, 実験をも行い, 理論 結果の妥当性を検証したものである。理論解析では曲 りばり理論に基づく基礎方程式の解より格間マトリッ クスを求め, それに格点マトリックスを組合せて伝達 マトリックスを作製し，伝達マトリックス法により振 動方程式を誘導した，具体的数値例としては, 鼓形コ

\footnotetext{
* 昭和 59 年 10 月 17 日 第 62 期全国大会講演会において講 演, 原稿受付 昭和 59 年 11 月 27 日.

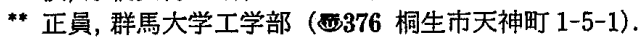

*** 学生員, 群馬大学大学院.
}

イルばねならびにたる形コイルばねを取り上げ,これ らの振動数を求め, 形状の変化に対する振動数の変化 を明らかにした。また従来解析されてきた円筒コイル ばねの結果をも求め, 本解との比較検討を行った。

\section{2. 解 析}

$2 \cdot 1$ 格間マトリックスの作製，円筒コイルばね

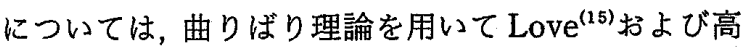
田 ${ }^{(6)} ら に よ り$ 静力学の基礎方程式が与えられ，応力問 題が解析された。，一方，沢登(14)はその方程式を用いて 剛性マトリックスを作製し, 有限要素法により円筒コ イルばねの振動を解析した。本報ではこれらの研究と 同じく曲りばり理論を用いて格間マトリックスを作製 する．静荷重を受ける曲りばりの基礎方程式は，

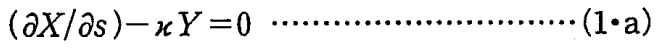

$$
\begin{aligned}
& (\partial Y / \partial s)+\varkappa X-\tau Z=0 \cdots \cdots \cdots \cdots \cdots \cdots \cdots \cdots(1 \bullet \mathrm{b})
\end{aligned}
$$

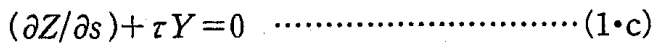

$$
\begin{aligned}
& (\partial T / \partial s)-x H=0 \quad \cdots \cdots \cdots \cdots \cdots \cdots \cdots \cdots \cdots(1 \cdot \mathrm{d}) \\
& (\partial H / \partial s)+x T-\tau M-Z=0 \cdots \cdots \cdots \cdots \cdots \cdots(1 \cdot \mathrm{e}) \\
& (\partial M / \partial s)+\tau H+Y=0 \cdots \cdots \cdots \cdots \cdots \cdots \cdots \cdots(1 \cdot \mathrm{f})
\end{aligned}
$$

ここで $X, Y, Z$ は断面力の $x, y, z$ 成分, $T$, $H, M$ は断面モーメントの $x, y, z$ 成分， $\varkappa$ は素線 軸の曲率， $\tau$ は素線軸のねじれ率， $s$ は素線軸に沿っ 
て測った素線の長さである（図 1)。

また, 断面力, 断面モーメントと変位および角変位 の間の関係式は次のようになる。

$$
\begin{aligned}
& X=E A\left(\frac{\partial u}{\partial s}-\varkappa v\right) \\
& T=G I_{p}\left(\frac{\partial \beta}{\partial s}+\varkappa \frac{\partial w}{\partial s}+\varkappa \tau v\right) \\
& H=-E I_{z}\left(\frac{\partial^{2} w}{\partial s^{2}}+2 \tau \frac{\partial v}{\partial s}-\varkappa \beta-\tau^{2} w+\varkappa \tau u\right) \\
& M=E I_{y}\left(\frac{\partial^{2} v}{\partial s^{2}}+\varkappa \frac{\partial u}{\partial s}-2 \tau \frac{\partial w}{\partial s}-\tau^{2} v\right) \cdots(2 \cdot \mathrm{d}) \\
& \delta=-\{(\partial w / \partial s)+\tau v\} \\
& \phi=(\partial v / \partial s)+\varkappa u-\tau w \\
& \varkappa=\left(\cos ^{2} \alpha\right) / R, \tau=(\sin 2 \alpha) /(2 R) \\
& \partial s / \partial \theta=R / \cos \alpha
\end{aligned}
$$

ここで, $I_{p}$ は素線軸まわりの断面二次極モーメン 卜， $I_{y}, I_{z}$ はそれぞれ $y$ 軸， $z$ 軸まわりの断面二次モ 一メント, $u, v, w$ は素線軸変位のそれぞれ $x, y, z$ 成分， $\beta, \delta ， \psi$ は素線断面の回転角のそれぞれ $x, y$, $z$ 成分, $\alpha$ はピッチ角, $R$ はばね半径, $\theta$ はば权中心 軸まわりの角座標である.また $E$ は縦弾性係数， $G$ は 横弾性係数， $A$ は素線断面積である. 式 (1) と式 (2) が静的平衡状態で厳密に解けるので，コイルばね要素 内の変位を表す式として, 変位 $u, v, w$ と角変位 $\beta$, $\delta, \phi$ を用いる。

式 $(1 \cdot \mathrm{a}) \sim(1 \cdot \mathrm{c})$ より $X$ と $Z$ を消去することによ $\eta$,

$$
\left(\partial^{2} Y / \partial \theta^{2}\right)+Y=0
$$

式 $(1 \cdot \mathrm{c}) \sim(\mathrm{I} \bullet \mathrm{f})$ より $T, M, Z$ を消去することによ り,

$$
\left(\partial^{2} H / \partial \theta^{2}\right)+H=-(2 R \tan \alpha) Y
$$

式(2)から,

$$
\varkappa Y=E A\left(\frac{\partial^{2} u}{\partial s^{2}}-\varkappa \frac{\partial v}{\partial s}\right)
$$

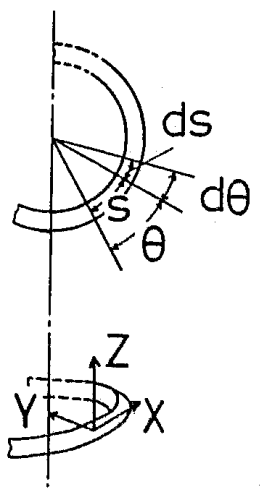

図 1 ばね要素と座標系

$$
\begin{aligned}
& \varkappa H=G I_{p}\left(\frac{\partial^{2} \beta}{\partial s^{2}}+\varkappa \frac{\partial^{2} w}{\partial s^{2}}+\varkappa \tau \frac{\partial v}{\partial s}\right) \\
& H=-E I_{z}\left(\frac{\partial^{2} w}{\partial s^{2}}+2 \tau \frac{\partial v}{\partial s}-\varkappa \beta\right. \\
& \left.-\tau^{2} w+\varkappa \tau u\right) \\
& -\tau H-Y=E I_{y}\left(\frac{\partial^{3} v}{\partial s^{3}}+\varkappa \frac{\partial^{2} u}{\partial s^{2}}\right. \\
& \left.-2 \tau \frac{\partial^{2} w}{\partial s^{2}}-\tau^{2} \frac{\partial v}{\partial s}\right)
\end{aligned}
$$

また式(6)から，u, $w, \beta$ が消去され，

$$
\frac{\partial^{5} v}{\partial \theta^{5}}+2 \frac{\partial^{3} v}{\partial \theta^{3}}+\frac{\partial v}{\partial \theta}=\frac{R^{2}}{E I_{z}}\left(R c_{1} Y+c_{2} H\right)
$$

ここに

$C_{1}=(4 / \cos \alpha)\left(1+I_{z} / I_{y}\right) \tan ^{2} \alpha$

$c_{2}=\left(2 E I_{z} / \dot{G} I_{p}\right) \sin \alpha+(2 \tan \alpha) / \cos \alpha$

$+\left(2 I_{z} / I_{y}\right) \sin \alpha \cdot \tan ^{2} \alpha$

ここで断面が円形の場合を考えると，断面二次極モ ーメントの関係は次のようになる.

$$
I_{p}=2 I_{y}=2 I_{z}
$$

よって式(7•b)は式 (8)を考慮すると次式になる.

$$
\left.\begin{array}{rl}
c_{1}= & (8 / \cos \alpha) \cdot \tan ^{2} \alpha \\
c_{2}= & (E / G) \cdot \sin \alpha+2 \sin \alpha \tan ^{2} \alpha \\
& +(2 \tan \alpha) / \cos \alpha
\end{array}\right\}
$$

式 (4)，(5)，(7)を解くことによって，v，Y，H が求まる. また, 式 $(1 \cdot a) \sim(1 \cdot \mathrm{e})$, 式 $(2 \cdot \mathrm{a}) \sim(2 \cdot \mathrm{d})$, 式(3・a)，(3・b)を解くことにより， $X, Z, T, M, u$, $w, \beta, \delta, \psi$ が求まる. そ机らを代表荷重 $Q_{0}$ と代表半 径 $R_{0}$ を用いて次のように無次化する.

$$
\begin{aligned}
u^{*} & =\frac{E I_{z}}{Q_{0} R_{0}^{3}} u, \quad v^{*}=\frac{E I_{z}}{Q_{0} R_{0}^{3}} v, w^{*}=\frac{E I_{z}}{Q_{0} R_{0}^{3}} w \\
\beta^{*} & =\frac{E I_{z}}{Q_{0} R_{0}^{2}} \beta, \delta^{*}=\frac{E I_{z}}{Q_{0} R_{0}^{2}} \delta, \psi^{*}=\frac{E I_{z}}{Q_{0} R_{0}^{2}} \psi \\
X^{*} & =X / Q_{0}, \quad Y^{*}=Y / Q_{0}, \quad Z^{*}=Z / Q_{0} \\
T^{*} & =\frac{T}{Q_{0} R_{0}}, H^{*}=\frac{H}{Q_{0} R_{0}}, M^{*}=\frac{M}{Q_{0} R_{0}}
\end{aligned}
$$

式 (9)を導入することにより, 角度 $\theta$ における状態 量 $\boldsymbol{X}(\theta)$ は次のように書くことができる。

$$
\boldsymbol{X}(\theta)=\boldsymbol{D}(\theta) \cdot \boldsymbol{E}
$$

ここに

$$
\begin{aligned}
& \boldsymbol{X}(\theta)=\left[u^{*} v^{*} w^{*} \beta^{*} \delta^{*} \phi^{*} X^{*} Y^{*} Z^{*} T^{*} H^{*} M^{*}\right]^{T}, \\
& \boldsymbol{D}(\theta)=\left[\begin{array}{cc}
d_{1,1} \cdots \cdots & d_{1,12} \\
\vdots & \vdots \\
\vdots & \vdots \\
d_{12,1} \cdots \cdots & d_{12,12}
\end{array}\right], \boldsymbol{E}=\left[\begin{array}{c}
E_{1} \\
\vdots \\
\vdots \\
E_{12}
\end{array}\right] \cdots(11)
\end{aligned}
$$

また, $d_{1,1} \sim d_{12,12}$ は付録 1 に示すとおりであり， 
$\boldsymbol{D}(\theta)$ は解マトリックス, $\boldsymbol{E}$ は積分定数マトリックス である。基本要素として角度 $0 \sim \theta_{i}$ の $i$ 番めの曲りば り要素定考えると，

$$
\begin{aligned}
& \theta=0 \text { て } \boldsymbol{X}(0)=\boldsymbol{X}_{i-1} \\
& \theta=\theta_{i} \text { て } \boldsymbol{X}\left(\theta_{i}\right)=\boldsymbol{X}_{\boldsymbol{i}}
\end{aligned}
$$

となり，これを用いて未定の積分定数マトリックスを 消去すると，格間マトリックス $\boldsymbol{F}_{i}$ が誘導される。

$$
\begin{gathered}
X_{i}=\boldsymbol{D}\left(\theta_{i}\right) \cdot \boldsymbol{D}(0)^{-1} \boldsymbol{X}_{i-1}=\boldsymbol{F}_{i} \boldsymbol{X}_{i-1}, \\
\boldsymbol{F}_{i}=\boldsymbol{D}\left(\theta_{i}\right) \cdot \boldsymbol{D}(0)^{-1} \ldots \ldots \ldots \ldots \ldots \ldots
\end{gathered}
$$

$2 \cdot 2$ 格点マトリックスの作製 格点の左右の関 係は素線の変位, 断面の回転角が連続であるとすると 次のようになる。

$$
\begin{aligned}
& u_{i}^{R}=u_{i}^{L}, v_{i}^{R}=v_{i}^{L}, w_{i}^{R}=w_{i}^{L} \\
& \beta_{i}^{R}=\beta_{i}^{L}, \delta_{i}^{R}=\delta_{i}^{L}, \phi_{i}^{R}=\psi_{i}^{L} \\
& X_{i}^{R}=X_{i}^{L}+m_{i}\left(\partial^{2} u_{i} / \partial t^{2}\right)_{i}^{L} \\
& Y_{i}^{R}=Y_{i}^{L}+m_{i}\left(\partial^{2} v_{i} / \partial t^{2}\right)_{i}^{L} \\
& Z_{i}^{R}=Z_{i}^{L}+m_{i}\left(\partial^{2} w_{i} / \partial t^{2}\right)_{i}^{L} \\
& T_{i}^{R}=T_{i}^{L}+J_{p}\left(\partial^{2} \beta / \partial t^{2}\right)_{i}^{L} \\
& H_{i}^{R}=H_{i}^{L}+J_{H}\left(\partial^{2} \delta / \partial t^{2}\right)_{i}^{L} \\
& M_{i}^{R}=M_{i}^{L}+J_{M}\left(\partial^{2} \psi / \partial t^{2}\right)_{i}^{L}
\end{aligned}
$$

ここで, $m_{i}$ は格点要素の質量, $J_{P}, J_{H}, J_{M}$ はそれ ぞれ素線軸, $y$ 軸, $z$ 軸まわりの回転慣性モーメント である.上記関係に式 $(9)$ 㐨よび $\lambda=p R_{0} \sqrt{\rho / G}$ を用い て無次元化を行うと, 格点 $i$ の右側 $R$ と左側 $L$ を結 ぶマトリックス方程式は,

$$
\boldsymbol{X}_{i}^{R}=\boldsymbol{P}_{i} \boldsymbol{X}_{i}^{L}
$$

ここに は無次元固有振動数, $p$ は円振動数, $\rho$ は 密度であり，格点マトリックス $\boldsymbol{P}_{i}$ は，

$$
\boldsymbol{P}_{i}=\left[\begin{array}{ccc}
f_{1,1} & \cdots \cdots & f_{1,12} \\
\vdots & \vdots \\
\vdots & \vdots \\
f_{12,1} \cdots \cdots & f_{12,12}
\end{array}\right]
$$

上式のマトリックス要素 $f_{1,1} \sim f_{12,12}$ は付録 2 に示す と扔りである.

$2 \cdot 3$ 振動解析 状態量べクトル $X_{i}$ は, 格間マ トリックス $\boldsymbol{F}_{i}$ と格点マトリックス $\boldsymbol{P}_{i}$ を用いて導か れる。

すなわち,

$$
X_{i}=T X_{0}
$$

ここに

$$
\boldsymbol{T}=\boldsymbol{F}_{i} \boldsymbol{P}_{i-1} \boldsymbol{F}_{i-1} \cdots \cdots \boldsymbol{F}_{2} \boldsymbol{P}_{1} \boldsymbol{F}_{1}
$$

したがって, $\boldsymbol{T}$ はマトリックス形で

$$
\boldsymbol{T}=\left[\begin{array}{ccc}
B_{1,1} & \cdots \cdots & B_{1,12} \\
\vdots & \vdots \\
B_{12,1} & \cdots & B_{12,12}
\end{array}\right]
$$

式(18)に括ける行列要素 $B_{1,1} \sim B_{12,12}$ は式(17)の行 例の乗算を数値的に行うことにより求められる。

兩端固定の境界条件を考慮すると，端点 $i=0$ わる びば权素線を $N$ 分割した場合他端 $i=N$ で素線軸変 位および素線断面の回転角はすべて零になるので, 式 （16）は次のように書かれる。

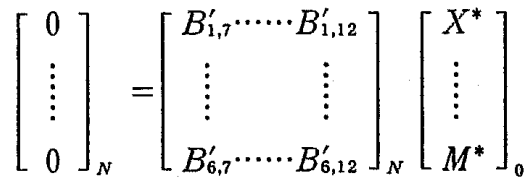

ここに $B_{\mathrm{l}, 7}^{\prime} \sim B_{6,12}^{\prime}$ は, 端部 $i=N$ における $B_{1,7}$ $\sim B_{6,12}$ の值である. 式(19)の係数行列式を零とおき, これを数值的に解くことにより無次元固有振動数 $\lambda$ を決定することができる。

\section{3. 数 值計 算 例}

数值計算例は，曲りばり理論に基づく基礎方程式の 解より格間マトリックスを求め，それに格点マトリッ クスを組合せて伝達マトリックスを作製し，伝達マト リックス法を用いて行った。まず本解の精度を検討す るために, 素線径 $4 \mathrm{~mm}$, コイル中心径 $26 \mathrm{~mm}$, 有効 巻数 6.5 巻, ピッチ角 $4.8^{\circ}$ の諸元の円筒ばねについ て計算を行った。円筒ば㱛の無次元固有振動数 $\lambda$ $\left(=p R_{0} \sqrt{\rho / G}\right)$ を表 1 に示す. 表 1 から，本解の結果と 沢登・福島 ${ }^{(14)}$ の結果はよく一致して扔り，また回転慣 性モーメントの影響は極めて少ないことがわかる，し たがって，以下の計算では回転慣性モーメントの項を 省略し, 分割は 1 巻を 12 分割として行う.

さて，任意形状ば权としてはじめに図 2 のような鼓 形ばねを想定する， $R_{1}$ は中央半径， $R_{2}$ は端部半径で；

表 1 円筒コイルばねの無次元固有振動数 $\left(\lambda=p R_{0} \sqrt{\rho / G}\right)$ の值

\begin{tabular}{|c|c|c|c|c|}
\hline Sode & 1 & 2 & 3 & 4 \\
\hline $\begin{array}{c}\text { Authors (Fotatory } \\
\text { inertia included) }\end{array}$ & 0.00835 & 0.00914 & 0.01039 & 0.01063 \\
\hline $\begin{array}{c}\text { Authors (Rotatory } \\
\text { inertia neglected) }\end{array}$ & 0.00835 & 0.00925 & 0.01039 & 0.01065 \\
\hline $\begin{array}{c}\text { Sawanobori } \\
\text {-Fukushina }\end{array}$ & 0.00826 & 0.00923 & 0.01038 & 0.01056 \\
\hline
\end{tabular}

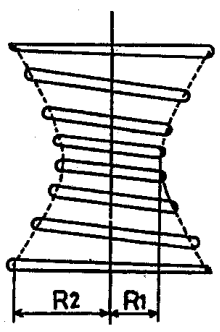

図 2 鼓形ばね 
計算では $R_{1}$ を代表半径 $\left(R_{0}=R_{1}\right)$ にとる.このばねで, 端部巻から数えて $N^{\prime}$ 番めの半径 $R$ は，

$$
R=R_{1}+\left(R_{2}-R_{1}\right)\left(1-2 N^{\prime} / N\right)^{2}
$$

ここに $N$ は有効巻数である.

図 3 では $R_{1}$ に対して $R_{2}$ を変化させたときの無次 元固有振動数の変化を示したものである. 縦軸は無次 元固有振動数 $\lambda$ を横軸は $R_{2} / R_{1}$ である. $R_{1} / d$ は, 代 表半径と素線半径の比である. $R_{1}$ に比べて $R_{2}$ が大き くなるにつれて固有振動数は減少し, $R_{2} / R_{1}$ が 1.0 の とき，三次と四次が近接しているのに対し， $R_{2} / R_{1}$ が 大きくなるにつれて三次は四次から離れて二次にある 程度近づいてくることがわかる.

図 4 では巻数 $N$ を変化させたときの無次元固有振 動数入の変化を示したものである。まず一次に整数巻

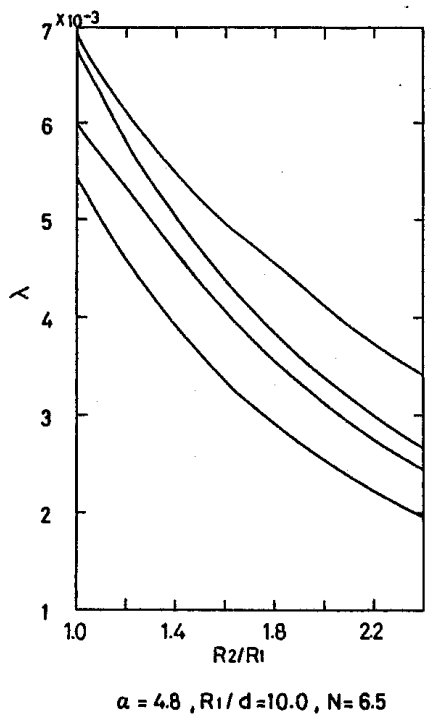

図 3 固有振動数に対する形状変化の影響

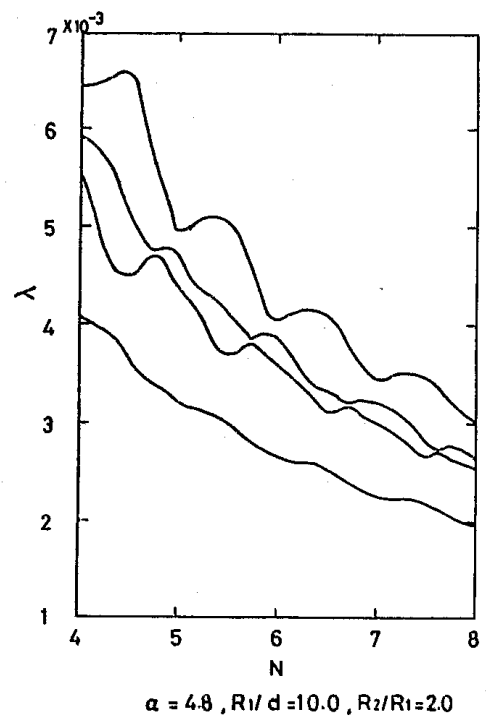

図 4 固有振動数に対する巻数変化の影㫪
から数えて, 0.25〜0.5 巻めのところで一度振動数が 上がる傾向がある. 二次は整数巻から数えて, 0.5 巻 め付近で下がり， 0.75 巻め付近で上がる傾向がある。 それは巻数が少ないほど顕著にみられる，三次，四次 においても巻数の位置はずれているが似たような傾向 がみられる。

図 5 はピッチ角 $\alpha$ を変化させたときの無次元固有 振動数入の変化を示したものである。ピッチ角が大き くなるにつれて一次, 二次, 三次が近接してくること がわかる。

次に図 6 のようなたる形ばねを考える。この場合も， 鼓形ばねと同様に $R_{1}$ は中央半径, $R_{2}$ は端部半径と し， $R_{1}$ を代表半径 $\left(R_{0}=R_{1}\right)$ とした。このば权におい て, 端部巻から数えて $N^{\prime}$ 番めの半径 $R$ は次のように 表される。

$$
R=R_{1}-\left(R_{1}-R_{2}\right)\left(1-2 N^{\prime} / N\right)^{2}
$$

ここに $N$ は有効巻数である.

図 7 では $R_{1}$ に対して $R_{2}$ を変化させたときの無次 元固有振動数の変化を示したものである. 縦軸は無次 元固有振動数 $\lambda$ を横軸は $R_{2} / R_{1}$ である. $R_{1}$ に比べて $R_{2}$ が小さくなるにつれて振動数が上がり，一次と二

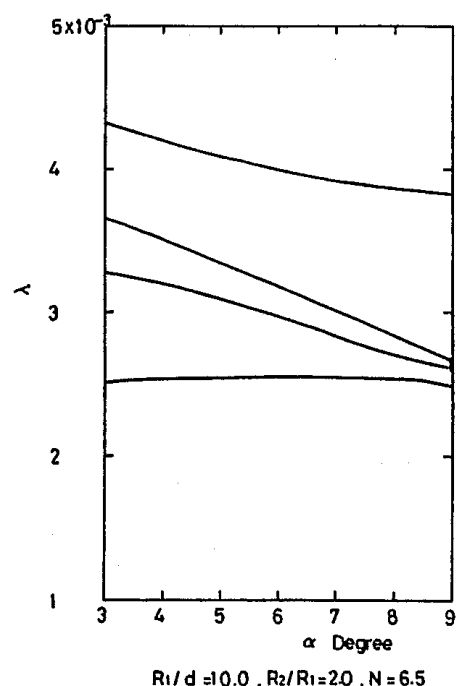

図 5 固有振動数に対するピッチ角変化の影響

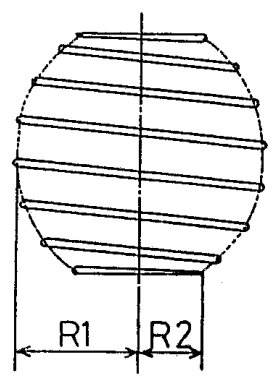

図 6 たる形ば权 
次は $R_{2} / R_{1}$ が 0.7 付近で特に近接している.

図 8 では巻数 $N$ を変化させたときの無次元固有振 動数 $\lambda$ の変化を示したものである，巻数を咨化させて も一次と二次, 三次と四次は近接している.

図 9 ではピッチ角 $\alpha$ を変化させたときの無次元固 有振動数入の変化を示したものである。このばねの場 合は固有振動数に関して，ピッチ角の影響が少ないこ とがわかる。

\section{4. 実験}

ひずみゲージをはりつけた前述の異形ばねを，一端 固定, 他端加振の取付け治具を用いて, 加振器に結合 する。ここにひずみゲージは鼓形ばねでは端部から 1 巻め，たる形ばれでは端部から 2 巻めに取付けた，加 振器によりコイル中心軸方向に加振し，ば稀の応答を 動ひずみ湘定器とオシロスコープによって測定し，固 有振動数を決定した。図 10 は実験装置を示したもので

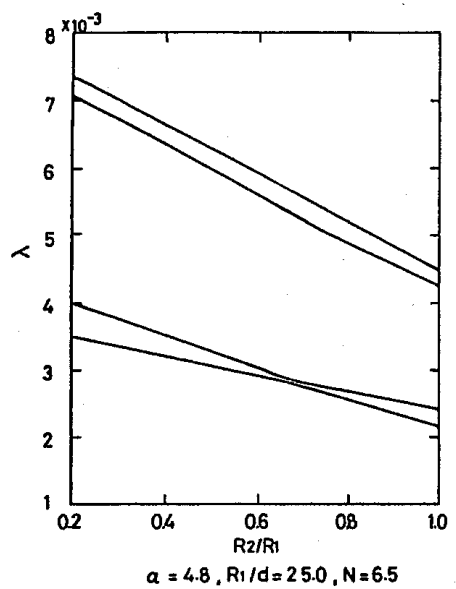

図 7 固有振動数に対する形状変化の影響

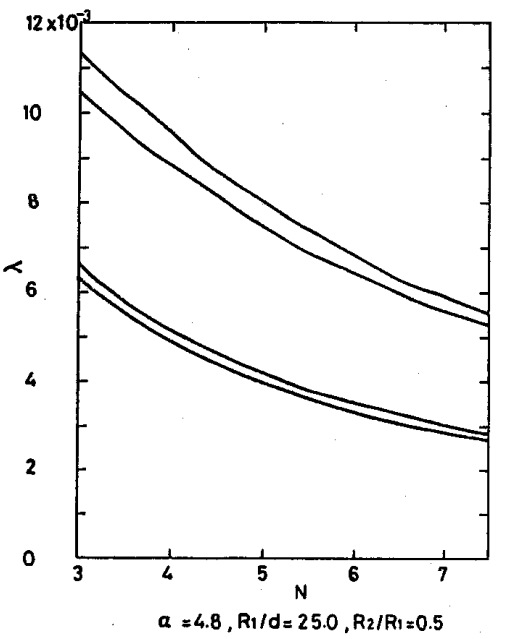

図 8 固有振動数に対する巻数変化の影響
ある。また寒験で用いたば极の材料は SWOSC-Vで その他の諸元は以下に示すと抢りである。

鼓形ば权： $\alpha=0.08378 \mathrm{rad}\left\{4.8^{\circ}\right\}, N=6.5$

$$
\begin{aligned}
& R_{1}=13.0 \mathrm{~mm}, d=1.3 \mathrm{~mm} \\
& R_{2}=13.0,15.6,20.8,26.0 \mathrm{~mm}
\end{aligned}
$$

たる形ばね： $\alpha=0.08378 \mathrm{rad}\left\{4.8^{\circ}\right\}, N=6.5$

$$
\begin{aligned}
& R_{1}=25.0 \mathrm{~mm}, d=1.0 \mathrm{~mm} \\
& R_{2}=25.0,20.0,15.0,10.0 \mathrm{~mm}
\end{aligned}
$$

鼓形ばね、たる形ばねにおける固有振動数に対する形 状変化について, ピッチ角 $\alpha$, 巻数 $N$, 中央半径 $R_{1}$ と素線半径 $d$ の比 $R_{1} / d$ を一定にして, 数値計算結果 と実験結果の比較を行った。

図 11 は, $\alpha=4.8, N=6.5, R_{1} / d=10.0$ の 時の鼓 形ばねの場合である. 縦軸は固有振動数 $f(=p)$ $2 \pi)[\mathrm{Hz}]$ を横軸には $R_{2} / R_{1}$ をとってある. 丸印は $R_{2} /$ $R_{1}=1.0,1.2,1.6,2.0$ のときの実験值を示し，実線 は理論值を示す。

図 12 は， $\alpha=4.8, N=6.5, R_{1} / d=25.0$ の 時のた る形ばねの場合である、縦軸は固有振動数 $f[\mathrm{~Hz}]$ を横 軸には $R_{2} / R_{1}$ をとっている. 丸印は $R_{2} / R_{1}=0.4,0.6$,

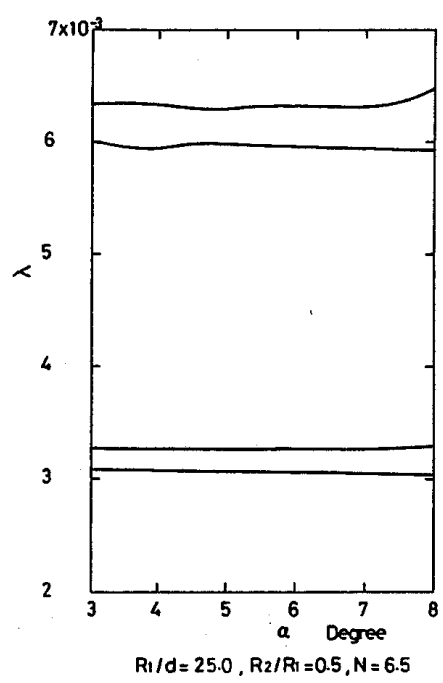

図 9 固有振動数に対するピッチ角変化の影響

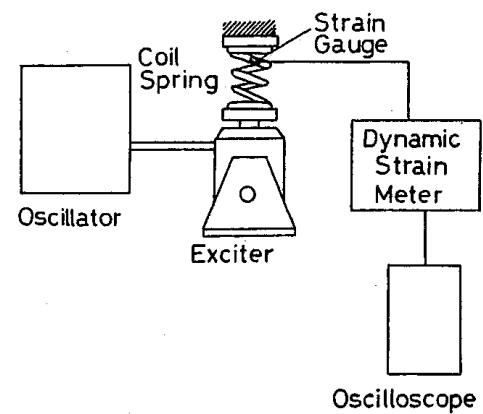

図 10 実験装置 


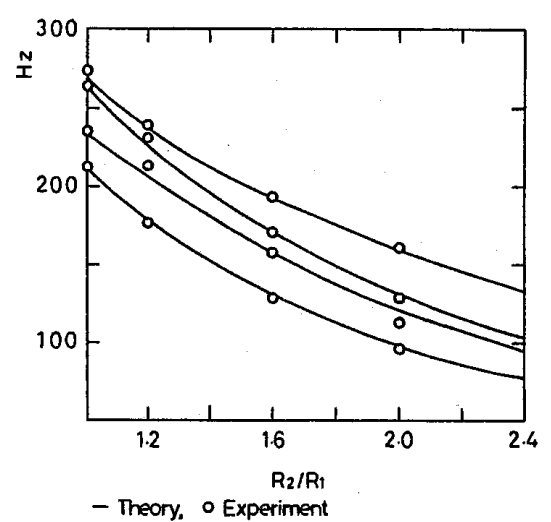

図 11 理論値と実験値の比較(鼓形ばね)

$0.8,1.0$ のときの実験值を示し, 実線は理論值を示 す. 図 11 と図 12 より本解の理論計算值と実験值は多 少の差はあるもののほぼ一致している.よって多少の 実験誤差はあるが，本解の妥当性が検証されたものと 思われる。

\section{5. 結言}

本報では, 任意形状ばねの振動を取扱い, 伝達マト リックス法を適用して，固有振動数を求め，また実験 も行い, 両結果の比較検討を行い, 一般形状ばねの振 動解析法を確立したものである。

その内容を要約すると,

（1）曲りばり理論に基づく基礎方程式の解より格 間マトリックスを求め, それに格点マトリックスを組 合せて伝達マトリックスを作製し，伝達マトリックス

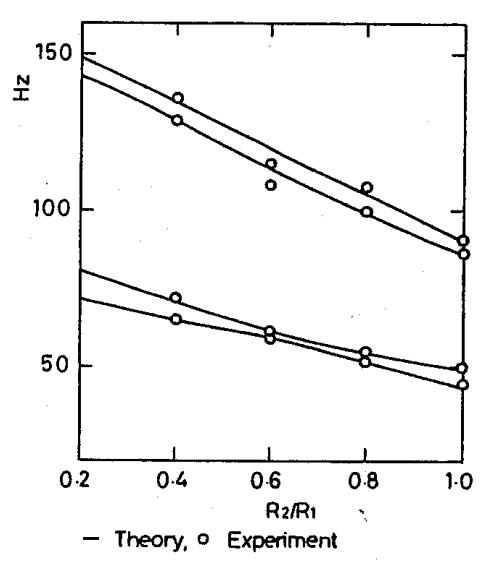

図 12 理論值と実験値の比較(たる形ばね)

法を用いて, 数値計算を行い, 固有振動数を決定し た.

（2）数値計算では，素線の回転慣性モーメントを 考慮した場合としない場合の計算を行ったところ，両 者の差は極めて小さく，実用上は素線の回転慣性モー メントの影響を省略してもさしつかえないことがわか った.

（3）具体例として，鼓形ばねおよびたる形ばねを とりあげ，それらの振動数に対する理論結果と実験結 果の比較検討を行ったところ両結果はよく一致し, 本 報の理論を使用して任意形状ばねの固有振動数を計算 できることが明らがされた。

本研究の実験に用いたばねは村田発條(株)の提供に よるものである.ここに記して謝意を表する。

付録1． 格間マトリックスの要素

式(11)のマトリックス要素は下記のとおりである.

$$
\begin{aligned}
& d_{1,1}=\psi^{3}\left[\bar{c}_{3}\left\{2 \theta S_{\theta}-\left(\theta^{2}-2\right) C_{\theta}\right\} C_{\alpha}-\bar{C}_{4}\left\{\left(3 \theta^{2}-6\right) C_{\theta}+\left(\theta^{3}-6 \theta\right) S_{\theta}\right\} C_{\alpha}-C_{\theta} / \bar{S}^{2}\right] \\
& d_{1,2}=\psi^{3}\left[-\bar{C}_{3}\left\{2 \theta C_{\theta}+\left(\theta^{2}-2\right) S_{\theta}\right\} C_{\alpha}-\bar{C}_{4}\left\{\left(3 \theta^{2}-6\right) S_{\theta}-\left(\theta^{3}-6 \theta\right) C_{\theta}\right\} C_{\alpha}-S_{\theta} / \bar{S}^{2}\right] \\
& d_{1,3}=-\psi^{3}\left(\bar{C}_{2} / 8\right)\left\{2 \theta S_{\theta}-\left(\theta^{2}-2\right) C_{\theta}\right\} C_{\alpha}, d_{1,4}=\psi^{3}\left(\bar{C}_{2} / 8\right)\left\{2 \theta C_{\theta}+\left(\theta^{2}-2\right) S_{\theta}\right\} C_{\alpha} \\
& d_{1,5}=\psi^{3} \theta C_{\alpha}, d_{1,6}=\psi^{3} C_{\alpha} S_{\theta}, d_{1,7}=-\phi^{3} C_{\alpha} C_{\theta}, d_{1,8}=\psi^{3}\left(C_{\theta}+\theta S_{\theta}\right) C_{\alpha} \\
& d_{1,9}=\psi^{3}\left(S_{\theta}-\theta C_{\theta}\right) C_{\alpha}, d_{1,10}=\psi^{3} \theta /\left(\bar{S}^{2} C_{\alpha}\right), d_{1,11}=\psi^{3} / \bar{S}^{2} \\
& d_{2,1}=\psi^{3}\left(\bar{c}_{3} \theta^{2} S_{\theta}-\bar{C}_{4} \theta^{3} C_{\theta}\right), d_{2,2}=-\psi^{3}\left(\bar{c}_{3} \theta^{2} C_{\theta}+\bar{c}_{4} \theta^{3} S_{\theta}\right), d_{2,3}=-\psi^{3}\left(\bar{C}_{2} / 8\right) \theta^{2} S_{\theta} \\
& d_{2,4}=\psi^{3}\left(\bar{c}_{3} / 8\right) \theta^{2} C_{\theta}, d_{2,5}=\psi^{3}, \quad d_{2,6}=\psi^{3} C_{\theta}, d_{2,7}=\psi^{3} S_{o}, d_{2,8}=\psi^{3} \theta C_{\theta}, d_{2,9}=\psi^{3} \theta S_{\theta} \\
& d_{3,1}=\phi^{3}\left\{-e_{1,1} C_{\theta}+e_{1,2}\left(C_{\theta}+\theta S_{\theta}\right)+e_{1,3}\left(2 C_{\theta}+2 \theta S_{\theta}-\theta^{2} C_{\theta}\right)+e_{1,4}\left(\theta^{3} S_{\theta}+3 \theta^{2} C_{\theta}-6 \theta S_{\theta}-6 C_{\theta}\right)\right\} \\
& d_{3,2}=\psi^{3}\left\{e_{2,1} S_{\theta}+e_{2,2}\left(S_{\theta}-\theta C_{\theta}\right)+e_{2,3}\left(\theta^{2} S_{\theta}+2 \theta C_{\theta}-2 S_{\theta}\right)+e_{2,4}\left(-\theta^{3} C_{\theta}+3 \theta^{2} S_{\theta}+6 \theta C_{\theta}-6 S_{\theta}\right)\right\} \\
& d_{3,3}=\psi^{3}\left\{-e_{3,1} C_{\theta}+e_{3,2}\left(\theta S_{\theta}+C_{\theta}\right)+e_{3,3}\left(-\theta^{2} C_{\theta}+2 \theta S_{\theta}+2 C_{\theta}\right)\right\} \\
& d_{3,4}=\psi^{3}\left\{e_{4,1} S_{\theta}+e_{4,2}\left(S_{\theta}-\theta C_{\theta}\right)+e_{4,3}\left(\theta^{2} S_{\theta}+2 \theta C_{\theta}-2 S_{\theta}\right)\right\} \\
& d_{3,5}=\phi^{3}\left\{e_{5} \theta+\theta\left(e_{12} / 2 g_{2}\right) / T_{a}\right\}, d_{3,6}=\psi^{3} e_{6} S_{\theta}, d_{3,7}=-\psi^{3} e_{7} C_{\theta} \\
& d_{3,8}=\psi^{3}\left\{-e_{8,2} C_{\theta}+e_{8,2}\left(C_{\theta}+\theta S_{\theta}\right)\right\}, d_{3,9}=\psi^{3}\left\{e_{9,1} S_{\theta}+e_{9,2}\left(S_{\theta}-\theta C_{\theta}\right)\right\} \\
& d_{3,10}=\psi^{3}\left\{e_{10} \theta+e_{11} \theta / T_{a}+e_{12} \theta\left(g_{1} / g_{2}\right)\right\}, d_{3,12}=\psi^{3} \\
& d_{4,1}=\psi^{2}\left(b_{1,1} C_{\theta}+b_{1,2} S_{\theta}+b_{1,3} \theta S_{\theta}+b_{1,4} \theta C_{\theta}+b_{1,5} \theta^{2} C_{\theta}+b_{1,6} \theta^{3} S_{\theta}\right) \\
& d_{4,2}=\psi^{2}\left(b_{2,1} S_{\theta}+b_{2,2} C_{\theta}+b_{2,3} \theta C_{\theta}+b_{2,4} \theta S_{\theta}+b_{2,5} \theta^{2} S_{\theta}+b_{2,6} \theta^{3} C_{\theta}\right)
\end{aligned}
$$




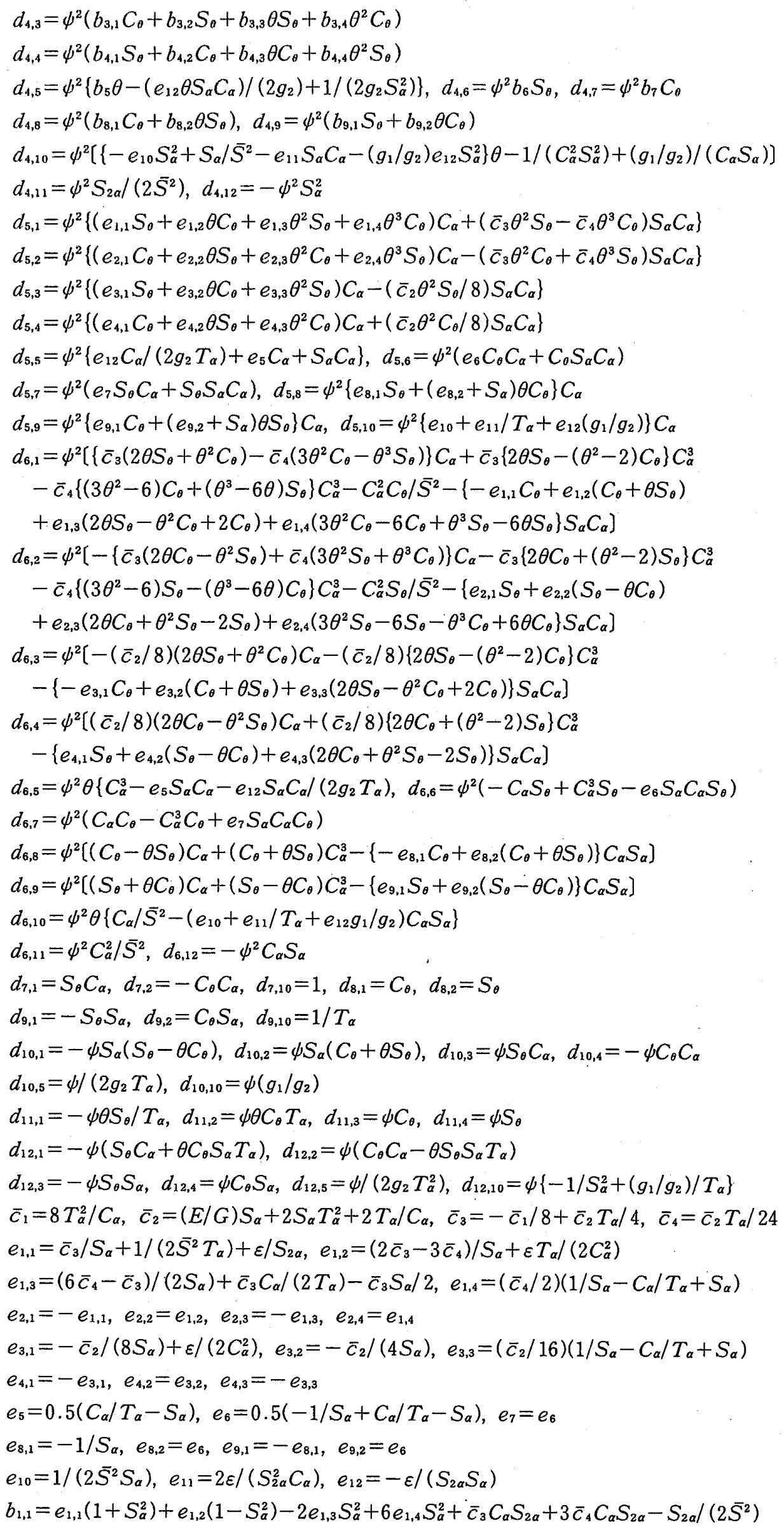




$$
\begin{aligned}
& b_{1,3}=-e_{1,2}\left(1+S_{\alpha}^{2}\right)+2 e_{1,3}\left(1-S_{\alpha}^{2}\right)+4 \bar{c}_{3} S_{\alpha}+6 e_{1,4} S_{\alpha}^{2}+\bar{c}_{3} S_{2 \alpha} C_{\alpha}+3 \bar{c}_{4} S_{2 \alpha} C_{\alpha} \\
& b_{1,5}=e_{1,3}\left(1+S_{\alpha}^{2}\right)+3 e_{1,4}\left(1-S_{\alpha}^{2}\right)+2 \bar{c}_{3} S_{\alpha}-6 \bar{c}_{4} S_{\alpha}-\left(\bar{c}_{3} / 2\right) S_{2 \alpha} C_{\alpha}-\left(3 \bar{c}_{4} / 2\right) S_{2 \alpha} C_{\alpha} \\
& b_{1,2}=-1 / C_{\alpha}, b_{1,4}=-T_{\alpha}^{2} / C_{\alpha}, b_{1,6}=-e_{1,4}\left(1+S_{\alpha}^{2}\right)+2 \bar{c}_{4} S_{\alpha}-\left(\bar{c}_{4} / 2\right) S_{2 \alpha} C_{\alpha} \\
& b_{2,1}=b_{1,1}, b_{2,2}=-b_{1,2}, b_{2,3}=-b_{1,3}, b_{2,4}=b_{1,4}, b_{2,5}=b_{1,5}, b_{2,6}=-b_{1,6} \\
& b_{3,1}=e_{3,1}\left(1+S_{\alpha}^{2}\right)+e_{3,2}\left(1-S_{\alpha}^{2}\right)-2 e_{3,3} S_{\alpha}^{2}-\left(\bar{c}_{2} / 8\right) C_{\alpha} S_{2 \alpha} \\
& b_{3,3}=-e_{3,2}\left(1+S_{\alpha}^{2}\right)+2 e_{3,3}\left(1-S_{\alpha}^{2}\right)-\left(\bar{c}_{2} / 8\right) C_{\alpha} S_{2 \alpha}-\left(\bar{c}_{2} / 2\right) S_{\alpha} \\
& b_{3,2}=-T_{\alpha} / C_{\alpha}, b_{3,4}=e_{3,3}\left(1+S_{\alpha}^{2}\right)-\left(\bar{c}_{2} / 4\right) S_{\alpha}+\left(\bar{c}_{2} / 16\right) C_{\alpha} S_{2 \alpha} \\
& b_{4,1}=b_{3,1}, b_{4,2}=-b_{3,2}, b_{4,3}=-b_{3,3}, b_{4,4}=b_{3,4} \\
& b_{5}=-e_{5} S_{\alpha}^{2}+C_{\alpha} S_{2 \alpha} / 2, b_{6}=-e_{6}\left(1+S_{\alpha}^{2}\right)-2 S_{\alpha}+S_{2 \alpha} C_{\alpha} / 2, b_{7}=-b_{6} \\
& b_{8,1}=e_{8,1}\left(1+S_{\alpha}^{2}\right)+e_{8,2}\left(1-S_{\alpha}^{2}\right)+2 S_{\alpha}+S_{2 \alpha} C_{\alpha} / 2, b_{8,2}=b_{6}, b_{9,1}=b_{8,1}, b_{9,2}=-b_{6} \\
& g_{1}=e_{10}\left(C_{\alpha}^{3}-S_{\alpha}^{2} C_{\alpha}\right)+e_{11}\left(C_{\alpha}^{3} / T_{\alpha}-S_{\alpha} C_{\alpha}^{2}\right)+S_{\alpha} C_{\alpha} / \bar{S}^{2} \\
& g_{2}=e_{12}\left(S_{\alpha}^{2} C_{\alpha}-C_{\alpha}^{3}\right)+E I_{z} /\left(G I_{p}\right)
\end{aligned}
$$

上記以外の要素は零になる.ただし, $\psi=R / R_{0}, C_{\theta}=\cos \theta, S_{\theta}=\sin \theta, C_{\alpha}=\cos \alpha, S_{\alpha}=\sin \alpha$, $T_{\alpha}=\tan \alpha, S_{2 \alpha}=\sin 2 \alpha, \varepsilon=I_{z} / I_{y}, \bar{S}^{2}=A R^{2} / I_{z}$ であり, 円形断面ばねでは $\varepsilon=1$ となる.

付録 2. 格点マトリックスの要素

式(15)のマトリックス要素は下記のとおりである.

$$
f_{j, j}=1(j=1,12), f_{7,1}=f_{8,2}=f_{9,3}=-m_{i}^{*}, f_{10,4}=-J_{p}^{*}, f_{11,5}=J_{H}^{*}, f_{12,6}=-J_{M}^{*}
$$

上記以外の要素は零になる。またここに

$$
\begin{aligned}
m_{i}^{*} & =\delta \theta \bar{S}^{2} \lambda^{2} /\{2(1+\nu)\}, J_{p}^{*}=\delta \zeta^{2} \theta \bar{S}^{2} \lambda^{2} /\{4(1+\nu)\} \\
J_{H}^{*} & =J_{M}^{*}=\delta\left\{3 \zeta^{2}+(1 / \delta)^{2} \theta^{2}\right\} \theta \bar{S}^{2} \lambda^{2} /\{24(1+\nu)\} \\
\text { ただし }, \delta & =R_{0} / R, \zeta=d / R_{0}, \nu \text { はポアソン比である. }
\end{aligned}
$$

\section{文献}

(1) Wahl, A. M., Trans. ASME, 51 (1929), 185.

(2) Göhner, O., Ing. Arch., 1 (1929), 619.

(3) Goodier, J. N., Trans. ASME, 25 (1958), 466.

(4) Ókubo, H., Trans. ASME, 20 (1953), 273.

(5) Röver, A., VDI-Z, 57 (1913), 1906.

(6) Takata, M., Proc. 7th Jpn. Natl. Congr. Appl. Mech., (1958), 365.

（7）清水・ほか 2 名, 機諭, 27-179（昭和 35）, 1119.
（8）下関・ほか 3 名，機論，45-396，C(昭 53)，901.

（9）下関・早坂, 機論, 48-435, C (昭 57)， 1774

（10）長屋, 機構論, No. 840-15(昭 59), 138.

（11）佐藤・ ほか 5名, 機構論, No. 840-15(昭 59)， 146.

（12）井上・吉永, 機論, 27-179(昭 36), 1130.

（13）清水・ほか 2 名, 機論, 27-179(昭 36), 1138.

（14）沢登・福島, 機論, 49-439(昭 58), 422.

(15) Love, A.E. H., A Treatise on the Mathematical Theory of Elasticity, 4th ed. (1944), Dover. 